Limnol. Rev. (2020) 20, 4: 185-198

DOI 10.2478/limre-2020-0018

\title{
Importance of environmental flows in the Wimmera catchment, Southeast Australia
}

\author{
Ehsan Atazadeh" 2 *, Andrew Barton ${ }^{3}$, Jafar Razeghi' \\ ${ }^{1}$ Department of Plant Biology, Faculty of Natural Sciences, University of Tabriz, 29 Bahman Blvd, Tabriz 51666-14779, Iran, \\ e-mail: atazadeh@tabrizu.ac.ir ("corresponding author, E.A.); jafar_razeghi@tabrizu.ac.ir (J.R.) \\ ${ }^{2}$ Institute of Environment, University of Tabriz, 29 Bahman Blvd, Tabriz 51666-14779, Iran \\ ${ }^{3}$ Faculty of Science and Technology, Federation University, Ballarat, Vic 3353, Australia, e-mail: a.barton@federation.edu.au
}

\begin{abstract}
In this paper the environment, climate, vegetation, indigenous and European settlement history, stream flow patterns, water quality and water resources development in western Victoria, Australia are studied. The last part of the paper focuses on the MacKenzie River, a tributary of the Wimmera River located on the northern slopes of the Grampians Ranges in western Victoria, Australia. Water release along the MacKenzie River was regulated to improve water quality, stream condition and river health especially in the downstream reaches. The upstream section tends to receive water most days of the year due to releases to secure the requirements of water supply for the city of Horsham and its recreational and conservation values, which is diverted into Mt Zero Channel. Below this the middle and downstream sections receive a more intermittent supply. Annually, a total of $10,000 \mathrm{dam}^{3}$ of water is released from Wartook Reservoir into the MacKenzie River. Of this volume, only about 4,000 dam ${ }^{3}$ was released explicitly for environmental purposes. The remaining 6,000 $\mathrm{dam}^{3}$ was released to meet consumptive demands and to transfer water to downstream reservoirs. The empirical data and models showed the lower reaches of the river to be in poor condition under low flows, but this condition improved under flows of $35 \mathrm{dam}^{3}$ per day, as indicated. The results are presented to tailor discharge and duration of the river flows by amalgamation of consumptive and environmental flows to improve the condition of the stream, thereby supplementing the flows dedicated to environmental outcomes. Ultimately the findings can be used by management to configure consumptive flows that would enhance the ecological condition of the MacKenzie River.
\end{abstract}

Key words: environmental flows, river management, aquatic ecology, aquatic biodiversity

\section{Introduction}

The average annual rainfall across Australia is $<500 \mathrm{~mm}$. However, rainfall is highly variable across much of Australia with a great deal of interannual variability; as such, periods of drought and flooding are very common (BoM 2014). The climate of southeast Australia (including western Victoria) is driven by three main climatic modes including: the El Nińo-Southern Oscillation (ENSO), the Southern Annular Mode (SAM) and the Indian Ocean Dipole (IOD) (Nicholls 1988; Power et al. 1999; Kiem et al. 2003; Kiem and Franks 2004; Gillett et al. 2006; Meyers et al. 2007; Murphy and Timbal 2008; Barr 2010; BoM 2014).

The ENSO plays a significant role in rainfall variability across eastern Australia (Nicholls 1988; Meyers et al. 2007), its variability is depicted as the Southern Oscillation Index (SOI) which is calculated by the sea-level pressure difference between Tahiti and Darwin (Barr 2010; BoM 2014). In the neutral state the south east trade winds bring warm and humid air towards Australia and the western Pacific and keep the central Pacific Ocean slightly cool. El Nino relates to the negative phase of ENSO and is associated with warm ocean water in the central and east-central regions of the equatorial Pacific Ocean. The consequence of prolonged El Nińo phases for eastern Australia are extended periods of severe drought (Wang and Hendon 2007). La Nina is the positive phase of ENSO and refers to the extensive cool ocean water off the central and 
eastern tropical Pacific Ocean. La Nińa conditions strengthen the south-east trade winds which drive and enhance wet conditions across the eastern and northern regions of Australia. A larger than usual number of tropical cyclones from November to April (the cyclone season) are associated with La Nińa activity (BoM 2014).

The Southern Annular Mode (SAM) is defined as a north-south movement of the westerly wind belt which is prevalent in the middle and high latitudes of the southern hemisphere (Marshall 2003). SAM (or the Antarctic Oscillation) is one of the main rainfall drivers in southern Australia. During periods of a positive SAM, the strong westerly wind belt contracts towards Antarctica. Therefore, the wind pressures across southern Australia are weaker than normal, restricting the penetration of cold and wet weather across southern Australia (Karpechko et al. 2009). It has been reported that a positive SAM was the main contributor to the Millennium Drought which occurred in Australia between 1997 and 2010 (BoM 2014). During a negative SAM, the strong westerly wind belt expands towards the equator and leads to an increase in rainfall and storms across southern Australia (Hendon et al. 2007; BoM 2014). The strength of the SAM has been established by employing a number of statistical methods (Marshall 2003; Goodwin et al. 2004; Fogt and Bromwich 2006).

The Indian Ocean Dipole (IOD) manifests as the difference in sea surface water temperature between the eastern and western regions of the Indian Ocean (Feng and Meyers 2003; Cai et al. 2009). The activities of the IOD affect the countries around the Indian Ocean Basin such as Australia, Indonesia and Papua New Guinea. The mechanism of the IOD is similar to ENSO and it has a significant role in influencing rainfall variability across Australia (Saji and Yamagata 2003). During a positive phase, seasurface temperatures increase in the western Indian Ocean and winds blow from the east causing Australia to experience less rainfall as a result of the prevailing offshore winds. During a negative phase of the IOD the sea surface temperature increases in the eastern Indian Ocean and the prevailing winds are from the west toward Australia bringing onshore winds and more rain across Australia (Feng and Meyers 2003; Saji and Yamagata 2003; BoM 2014).

The MacKenzie River, which drains the north- ern slopes of the Grampians Ranges in western Victoria, is one of the main tributaries of the Wimmera River (Fig. 1). The headwaters feed into Wartook reservoir in the Grampians National Park, which has a maximum capacity of $29,360 \mathrm{dam}^{3}$. The river flows approximately $50 \mathrm{~km}$ from Wartook Reservoir before its confluence with the Wimmera River. The catchment lies to the south of the city of Horsham and covers an area of approximately $597 \mathrm{~km}^{2}$ (Earth Tech 2004). The MacKenzie River is classified as a highly modified river due to the consequences of this anthropogenic modification, where consumptive flows will dominate the flow regime in some years.

This review is focused on environmental flow assessments and the ecological health of rivers in western Victoria, Australia. It also focuses on identifying connections among river flow regimes, river health and adaptive management to inform water managers, stakeholders and decision-makers by illustrating an adaptive management approach and monitoring to determine the effectiveness of management measures.

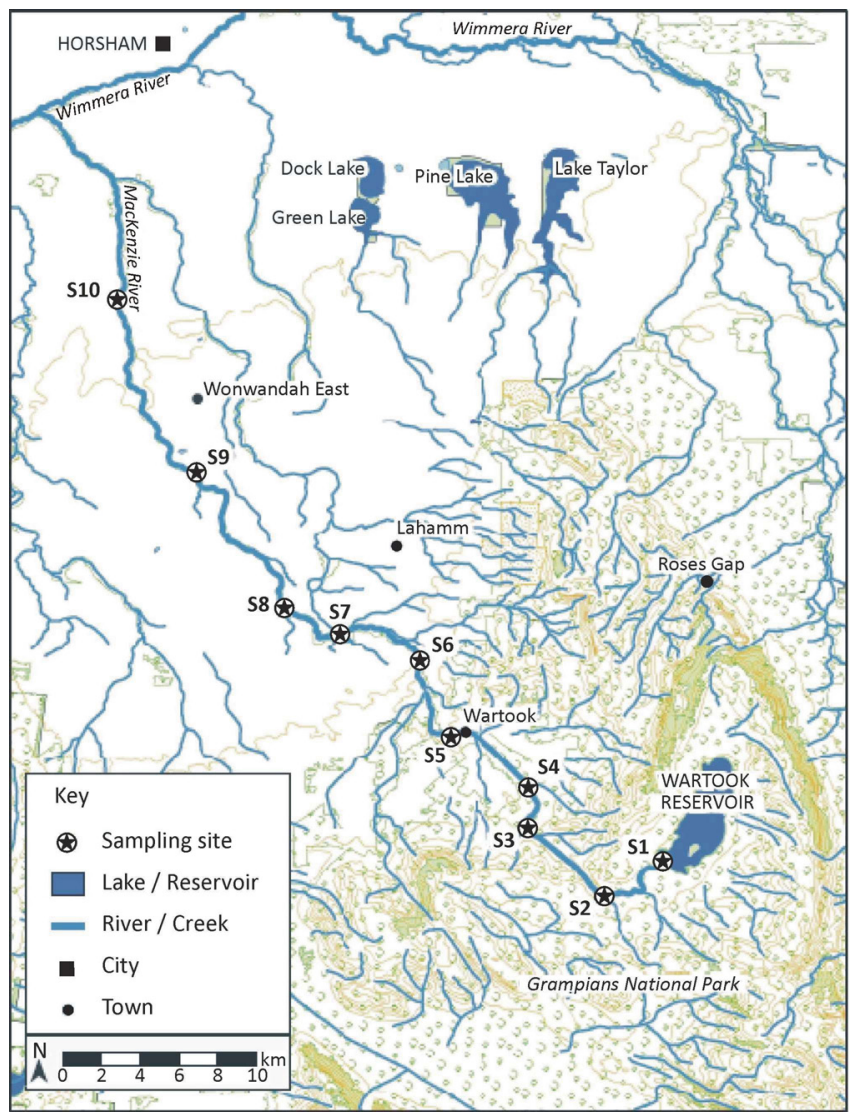

Fig. 1. Location of the ten sampling stations along the MacKenzie River system in the Wimmera catchment 


\section{Australian freshwater ecosystems}

Australian freshwater ecosystems have distinctive ecological features, aquatic biota, energy flow and physicochemical characteristics when compared to other inland waters across the world (Lake et al. 1985; Lake et al. 2000; Nielsen et al. 2003; Bond et al. 2008; Lake 2011; Boulton et al. 2014; Atazadeh 2017; Atazadeh et al. 2020). More than two thirds of Australia is arid or semi-arid, and as a result extensive areas can only support intermittent streams and shallow ephemeral lakes (Boulton and Brock 1999). The majority of rainfall (based on average annual totals) occurs in TAS, VIC, NSW, QLD, NT and northern WA. Therefore, many Australian river systems have variable flows with low discharge rates (Lake et al. 1985; Boulton and Brock 1999). In this dry environment, perennial freshwater ecosystems are restricted to the humid eastern, southern and tropical zones which elevate their importance for use by humans, wildlife and stock. Overall, there are three main freshwater systems in Australia, namely: (i) coastal systems; (ii) the Kati Thanda-Lake Eyre system; (iii) the Murray-Darling system.

The Murray-Darling system is the most iconic and important freshwater system in Australia owing to its high level of development for irrigated agriculture. The two main basins, the Darling in the north and the Murray in the south and east, are together known as the Murray-Darling Basin, one of the largest river basins in the world. The MurrayDarling Basin spans approximately 1.056 million $\mathrm{km}^{2}$ and contains 440,000 rivers and streams and 30,000 wetlands (BoM 2016). The Basin extends over NSW, ACT, VIC and the southeast parts of QLD and SA. The rivers of the Murray-Darling Basin experience variable flows, both seasonally and interannually. resulting in the formation of a variety of river types including; ephemeral, semi-arid and permanent rivers (Brandis et al. 2009). Most rivers in the southern basin are highly regulated due the construction of many weirs and dams over the last 90 years (BoM 2016).

Regulation and a high level of abstraction have combined with a highly variable climate and subdued topography to affect stream flows and the distribution of water across the basin. Therefore, the hydrology, flow pattern, river forms, water quality characteristics, aquatic biota, physical processes, ecological attributes and ecosystem functions have changed across the basin (Gehrke et al. 1995; Maheshwari et al. 1995; Maier et al. 2001; Brandis et al. 2009; Kingsford 2011; Mosley et al. 2012).

\section{Western Victoria}

The western Victorian region is situated between $36-38^{\circ} \mathrm{S}$ latitude and $141-144^{\circ} \mathrm{E}$ longitude. It is bounded by the Wimmera-Mallee in the north, Goldfields in the east, the Southern Ocean and Bass Strait in the south and South Australia to the west. The region of western Victoria can be divided into two geomorphic zones (upland and lowland) based on environmental features and ecological characteristics; the uplands of the Great Diving Range and the Grampians and Otway Ranges (Gell 1997; Barr 2010), and the lower lying Volcanic Plains. The Otway Ranges lie to the south of the Plains and are among the most humid parts of the state. The Great Dividing Range lies along the eastern margin of Australia but runs east-west in Victoria, essentially dividing the state into the southern plains and, to the north, the plains of the southern Murray-Darling Basin.

The Grampians are an isolated range that is akin to a western extension of the Great Dividing Range. The highest peak within the Grampians Ranges, at $1167 \mathrm{~m}$ above the sea level, is Mount William (Clark 2010). The colonisation of western Victoria by Europeans (c. $1850 \mathrm{CE}$ ) dramatically increased the human population, resulting in extensive anthropogenic modification to the regional environment (Clarke 2002).

\section{Geology, geomorphology and vegetation}

The geology of western Victoria is diverse and mainly composed of Cainozoic and Palaeozoic sedimentary rocks of marine origin, with areas of intrusive igneous rocks (Lawrence 1975; Cayley and Taylor 1997; Birch 2003). The geology of western Victoria was formed by Tasmanides which includes Cambrian Delamerian and Lachlan as a result of deformation of Ordovician to Silurian mudstone (Birch 2003; Lisitsin et al. 2013). Therefore, western Victoria (including Grampians) lies on a diverse range of Cambrian bedrock (Cayley and Taylor 1997). The rock materials mainly contain sedimentary (mostly quartz, sandstone and red siltstone) and igneous 
(granites and Rocklands Volcanic) forms called the Grampians Group (Cayley and Taylor 1997; Birch 2003). The volcanoes in southwest Victoria can be divided into four types including lava volcanos, maars, scoria volcanos and volcanic complexes (Joyce 1988; Barr 2010). In the uplands of the Wimmera ,the geology ranges from Cambrian metasediments and Devonian granites, while it changes to younger tertiary strata in the Wimmera Plains.

Geomorphological studies have shown that western Victoria was created by tectonic forces and is, generally (including the uplands), much lower and less rugged than eastern Victoria (Rosengren 1999). The uplands of western Victoria can be divided into three geomorphic units including: Dissected Uplands or Midlands, Prominent Ridges of the Grampians and Dissected tablelands or Dundas tablelands. The soil in western Victoria has different varieties, mostly sandy with moderate fertility which supports plant cover and vegetation (Willatt and Pullar 1984; Enright et al. 1997). Plant cover, vegetation and forest in eastern Victoria is greater than western Victoria.

\section{Climate and weather}

Generally the climate of western Victoria is similar to the Mediterranean: cool and wet in winter, and warm to hot in summer. However, the rainfall in western Victoria varies from more than $1600 \mathrm{~mm}$ in the southwest and the Grampians to less than $300 \mathrm{~mm}$ in the northern plains (Ecological Associates 2004), resulting in the northwest being semi-arid, and the southeast being very humid, particularly in the Otway Ranges (House et al. 2002). The majority of this precipitation occurs during late autumn (April-May), winter (June-August), and early spring (September). However, rainfall also occurs in varying amounts during all other months of the year (BoM 2014). The ENSO and IOD are prominent during summer and spring, and the SAM is very important during winter in Western Victoria. The ENSO brings warm and humid air to western Victoria under its natural phase, whereas the negative phase of ENSO brings extended periods of severe drought particularly when it combines with a positive IOD. Conversely, the positive phase of the ENSO brings extensive cool ocean weather to west- ern Victoria.

\section{Wimmera catchment}

The Wimmera River is an inland flowing, intermittent river within a catchment area of $23,500 \mathrm{~km}^{2}$ located in the Grampians region of western Victoria. Whilst it is situated in the Murray-Darling Basin its flow is limited by the dune fields of northwest Victoria and so its flow ends in terminal lakes (Alluvium 2013). The Wimmera River is one of the largest endoreic waterways in Victoria (SKM 2002; Ecological Associates 2004; Alluvium 2013). The river rises in the Mt Buangor State Park and the Pyrenees Ranges and flows through Crowlands, Glenorchy, Horsham, Dimboola, Jeparit and finally terminates at Lake Hindmarsh, although water can penetrate into Lake Albacutya and the Outlet Creek system after extended wet periods (e.g. 1973-1975). The Wimmera River has several tributaries including the Mt Cole Creek, Six Mile Creek, Seven Mile Creek, Sheepwash Creek, Mt William Creek, Glenpatrick Creek and Heifer Station Creek; but the main tributaries are the MacKenzie River, Burnt Creek and Norton Creek (Anderson and Morison 1989a-c; Ecological Associates 2004; Alluvium 2013).

There are a number of channels, pipelines and waterways in the system which supply and deliver water to various consumptive users including: urban usage, irrigation, water storages, environmental and recreational needs. In the Wimmera-Glenelg system there are a number of water storages including: Wartook Reservoir, Lonsdale Reservoir, Lake Bellfield, Lake Taylor and Lake Fyans (Wimmera system), and Rocklands and the Moora Moora Reservoirs (Glenelg System). The engineered WimmeraGlenelg system is complex because of the water supply operation itself, the different sized water storages and the varying demands from customers and the environment for water delivery (VEWH 2015). The efficiency and flexibility of the system allows waterway managers to transfer water between reservoirs. Furthermore, the facility of the system allows the off-stream storages to harvest water from channels and storages (Fig. 2).

\section{Environmental condition}

The Wimmera River catchment supports a diverse range of vegetation. The upper areas of the 


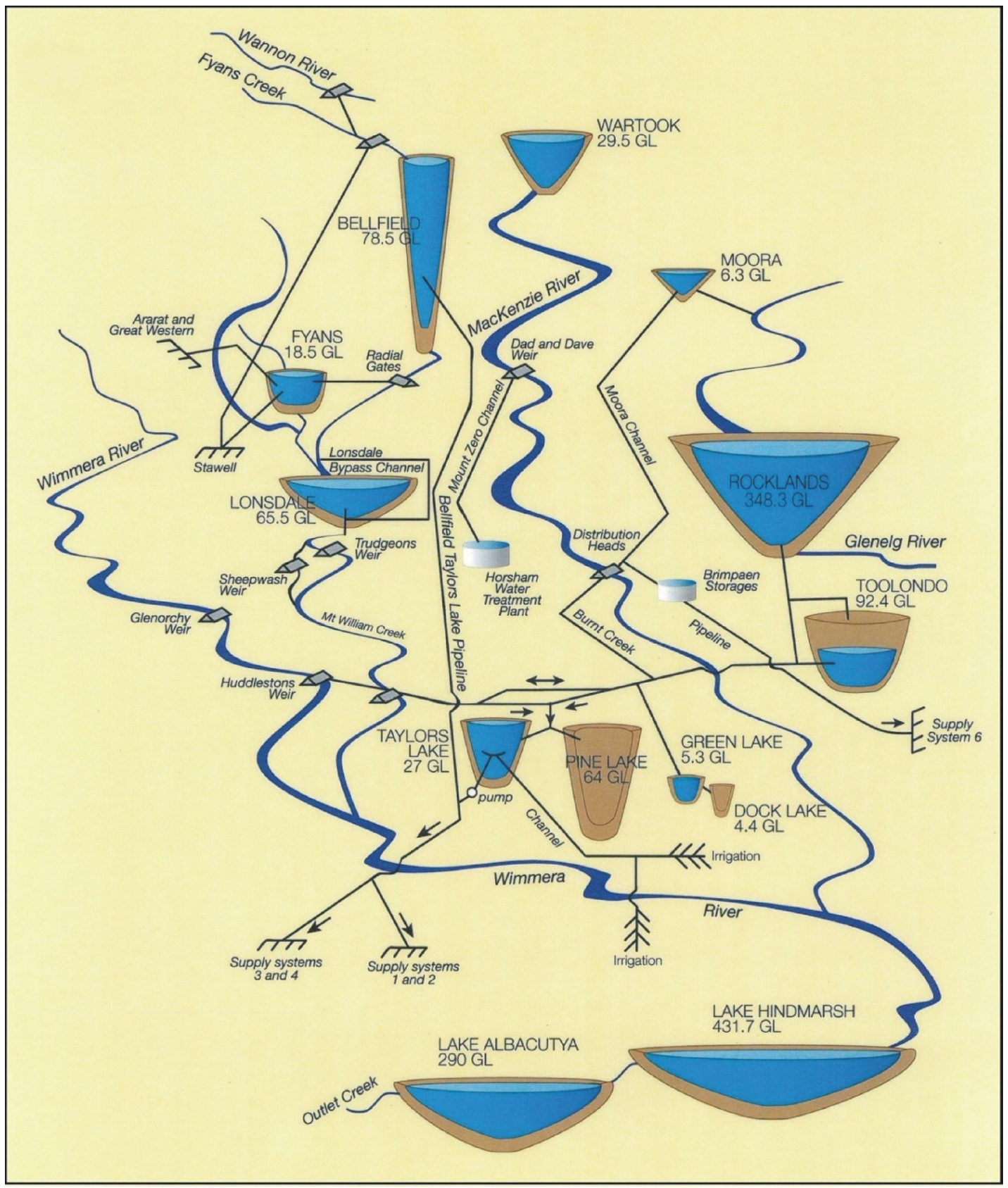

Fig. 2. Schematic diagram of the complex water supply in the Wimmera-Glenelg system

Source: GWMWater

Grampians ranges are covered by dense woodlands dominated by Eucalyptus species. In the lower parts of the catchment there are areas of open grassland with woodland communities of Buloke, Native Cypress Pine and eucalypt (WRCLPB 1997; SKM 2002). Since European settlement, the Wimmera River has been substantially modified, because the catchment land, particularly the fertile plains, have been extensively developed for agriculture. The Wimmera River catchment is used for crop and livestock production such as wheat, legumes and sheep (Fischer 1999; SKM 2002). This intense agricultural activity including irrigation, land clearing for farming and cropping, and more recently industrial activities such as the construction of the Wimmera Mallee pipeline project development, defines the catchment as highly modified (60\%) between 1994-2004 (Nathan and Lowe 2012).

The upper parts of the Wimmera River have been regulated (SKM 2002). Much of the length of 
the River has suffered from bank erosion caused by the clearing of plant cover and riparian vegetation (Anderson and Morison 1989a-c). Furthermore, fluctuations in the natural flow regimes along the river and its tributaries encourage the transport of sediment from upstream to downstream, and the deposition of those sediments into the lower reaches (RWC 1991). The lower reaches of the Wimmera River flow through semi-arid regions resulting in water loss through evaporation, percolation and seepage (Anderson and Morison 1989a-c; Alluvium 2013). The low-gradient of the catchment and water flow reduction restrict the River to a series of pools and small lakes in the mid and lower parts of the river, particularly in the drier months.

The Wimmera River and its tributaries (including the MacKenzie River, Burnt Creek and Norton Creek) provide habitat for different species including waterbirds, fish, platypus, amphibians, snails, mussels and macro-invertebrates; a number of which are listed as vulnerable or considered threatened in Australia (SKM 2002). Twelve fish species have been reported from the Wimmera River of which six are endemic to south-eastern Australia, including the River Blackfish (Gadopsis marmoratus) and Mountain Galaxias (Galaxias olidus) (DNRE 2000b; SKM 2002). Four fish species, one frog species and many plant species in the Wimmera River system are considered threatened (DNRE 2000c; SKM 2002, 2003). A number of other species in the catchment, such as Platypus (Ornithorhynchus anati$n u s$ ) and Water Rat (Hydromys chrysogaster), directly depend on the river environment for food and shelter. The aquatic ecosystem in the lower parts of the Wimmera River experiences stress due to poor water quality, largely as a result of increasing water salinity as the flow reaches the terminal lakes (SKM 2002). The terminal lakes of the Wimmera River (Lake Hindmarsh and Albacutya), when full, play a significant role in providing habitat for approximately 50 waterbird species such as the Great Egret (Ardea alba) and Freckled Duck (Stictonetta naevosa) both of which are listed as endangered in Victoria (DNRE 2000a). Moreover, Lakes Hindmarsh and Albacutya have unique and outstanding ecological characteristics such that Lake Albacutya is listed under the Ramsar Convention (SKM 2002).

\section{Natural phenomena in the Grampians Na- tional Park}

One of the main natural phenomena in southeast Australia is bushfire. Bushfires (wildfires) often occur in dry conditions and dense vegetation when dry winds blow from central Australia to the southeast. Some trees, particularly Eucalyptus, are prone to fire because their leaves contain highly flammable oils (Gill and Moore 1996). The Grampians National Park has dense vegetation which is composed mostly of Eucalyptus. Two strong bushfires occurred in the early months of 2006 and 2014 which affected the most of the Grampians National Park. According to the Country Fire Authority (CFA), 55,000 hectares of the Grampians region was burnt in January 2014. This greatly affected the vegetation of the MacKenzie River catchment such that the surrounds of Reach 1 and Reach 2 were burnt completely, with much of the canopy cover lost. The volume of large woody debris in the channel increased. It has been reported that bushfires play significant roles in structuring terrestrial plant communities and are a natural feature of Australian sclerophyll ecosystems (Whelan 1995). However, the impacts of the bushfire on freshwater ecosystems are not well documented (Cowell et al. 2006).

\section{Hydrological alterations}

The Wimmera catchment hydrology has been modified on account of the development of an irrigation system (e.g. Wimmera-Mallee pipeline), abstraction for the supply of water to urban, domestic and stock users, and the establishment of the Wimmera Mallee Domestic and Stock Supply System (WMDSS).

Grampians Wimmera Mallee Water (GWMWater) is the water agency responsible for the operation of the WMDSS, which captures and distributes water in the Wimmera and Glenelg catchment regions. The WMDSS is a complex network of channels, pipes and storages which captures large portions of the water in the system. It has significant impacts on flow regime characteristics; decreasing the magnitude and frequency of the flow before reaching Lakes Hindmarsh and Albacutya (Ecological Associates 2004).

The Wimmera River has been regulated since the construction of the Wartook Reservoir in 1887. The maximum annual flow of the river is 135,570 dam $^{3}$ (Horsham station) (SKM 2002). However, the annual flow regime can change from no flow, as 
occurred during the El Nińo of 1994; to 570,000 dam $^{3}$ which occurred in the La Nińa of 1956 (DWR 1989; SKM 2002). The natural flow of the river has been substantially modified due to the construction of reservoirs, weirs and locks along the catchment which together underpin the WMDSS, supplying water for agriculture, urban and domestic use (Anderson and Morison 1989a-c; SKM 2002; Ecological Associates 2004; Alluvium 2013).

The establishment of the WMDSS has resulted in further development of the Wimmera River system, which consequently has affected the flow regime in the Wimmera Catchment. The WMDSS diverts water from the Wimmera, Glenelg, Wannon, Murray and Goulburn Rivers and features 12 storages and 18,000 km channels (Western 1994; Overman 1996; Western et al. 1997; SKM 2002). The transfer of water and the system operation of the Wimmera River are very complex and the majority of the diversions have been organised from the Glenorchy and Huddleston weirs. The flow regime changes substantially below the Huddleston Weir and this affects the hydrology of the lower parts of the river (SKM 2002).

The water quality of the Wimmera River varies downstream. Overall, the river water has high salinity and high nutrient concentrations, and low dissolved oxygen levels (Anderson and Morison 1989a-c). The salinity of the water is high in both the upstream and downstream reaches but it is less in the midstream due to the diluting effect of water entering from the WMDSS at the Glenorchy Weir (Anderson and Morison 1989a-c; SKM 2002).

Additionally, the intrusion of saline groundwater into the lowland reaches in conjunction with a decreasing volume of water in the dry season, and high temperatures, increases the salinity of the water and saline pools can reach $>50,000 \mathrm{mg} \mathrm{dm}^{-3}$ (Anderson and Morison 1989a-c). The concentrations of phosphorus and nitrogen are moderate to high, particularly in the downstream reaches (Alluvium 2013), and are correlated with fluctuations in the rainfall and flow regime (SKM 2003). Increased algal growth due to eutrophication which creates restrictions within the channel lead to bank erosion, further impacting on the aquatic biota and habitats (Anderson and Morison 1989a-c; Craigie et al. 1999; SKM 2002). The low concentration of dissolved oxygen is another major issue for the management of the Wimmera River. The deple- tion of dissolved oxygen in water to $<3 \mathrm{mg} \mathrm{dm}^{-3}$ is common along the river and deoxygenation occurs at depths greater than $2 \mathrm{~m}$ in the water column, especially below Huddleston Weir (Anderson and Morison 1989a-c). It seems that groundwater contributes to stratification which then contributes to the deoxygenation of the lower layer of the river.

The development of hydro-ecological principles helps to better assess the in-stream flow requirements of riverine ecosystems. Bunn and Arthington (2002) developed a conceptual model with four hydro-ecological principles: (i) flow regime is a master variable in freshwater ecosystems, affecting channel form, distribution and abundance of species, and composition and diversity of aquatic communities; (ii) flow regime can have major impacts on life-history patterns, such as spawning and the recruitment of aquatic species; (iii) flow regime governs and maintains the lateral and longitudinal connectivity in channels that are very important for aquatic species; and (iv) natural flow regime prevents the introduction of exotic species into the system.

There are certain constraints on the release of this water, but where consumptive flow release operations are developed with environmental flow operations (10 dam da $^{3}$ per day for 12 months) a flow of 35 dam $^{3}$ per day for three days every two weeks as a top-up from consumptive flows can be achieved. Indeed, there are clear benefits that would accrue from integrating environmental flows and consumptive flow operations.

\section{MacKenzie River in Western Victoria}

The MacKenzie River, which drains the northern slopes of the Grampians Ranges in western Victoria, is one of the main tributaries of the Wimmera River (Fig. 11). The headwaters feed into Wartook Reservoir in the Grampians National Park, which has a maximum capacity of 29,360 dam³ ${ }^{3}$. The river flows approximately $50 \mathrm{~km}$ from Wartook Reservoir before its confluence with the Wimmera River. The catchment lies to the south of the city of Horsham and covers an area of approximately $597 \mathrm{~km}^{2}$ (Earth Tech 2004).

Water is released from Wartook Reservoir for multiple purposes; however, the water released is usually for consumptive use, and is directed through a network of distributary channels and as- 
sociated structures at different locations along the system, including Mt Zero Channel and Distribution Heads. Flows vary from year to year depending on seasonal inflows, although typically between 7,000 and 10,000 dam $^{3}$ is released each year from Wartook Reservoir into the upper MacKenzie River; of this volume one third of the released water was explicitly for environmental purposes. The remaining water was released to meet the consumptive demands and to transfer water to downstream reservoirs (GWMWater Storage Manager, pers. comm., July 17, 2015). As a consequence of this anthropogenic modification, the MacKenzie River is classified as a highly modified river (GWMWater 2012; GWMWater Storage Manager, pers. comm., July 17,2015$)$, where consumptive flows will dominate the flow regime in some years.

Wartook Reservoir and the Grampians National Park are highly recognised for their natural and recreational values. The Park supports a wide range of flora and fauna providing suitable conditions for riparian vegetation growth, and the existence of woodland and aquatic biota. However, the region is vulnerable to natural bushfire particularly in the dry season. Although there are large changes in the hydrology down the river, there is little variation in the geomorphological features. The main geomorphologic changes relate to vegetation encroachment on the channel. Dense riparian vegetation exists along the MacKenzie River from the headwaters in the Grampians National Park to the lower reaches nearer to Horsham. The vegetation is mostly composed of species of Eucalyptus, Leptospermum and Acacia. This area represents a suitable habitat for native biota such as: kangaroos and bird species like the Eastern Yellow Robin, Superb Fairy-wren, White Cockatoo and Rufous Night-heron. Furthermore, the MacKenzie River supports a great diversity of aquatic species, especially native fish. It also supports exotic fish species including trout, redfin, carp and mosquito fish (Anderson and Morison 1989a-c). Moreover, there still remains an important population of platypus in this river (Earth Tech 2004; Alluvium 2013). The MacKenzie River also has great potential for eco-tourism since, among a range of natural attractions, it has examples of Aboriginal and European heritage and offers a good place for camping at Zumsteins and MacKenzie Falls, as well as recreational fishing along the river.

\section{Why MacKenzie River?}

Over the last two decades ecological monitoring in the Wimmera catchment showed that flow regime and water quality are critical characteristics that affect the river's health, particularly in its lower reaches (Anderson and Morison 1989a-c; Westbury et al. 2007). One of the main priorities for the Wimmera Catchment Management Authority (WCMA) is to find a sustainable solution to mitigate the threats which are affecting the condition of the Wimmera River. For ecological risk assessment, predictive tools have been developed by the WCMA for managing environmental flow allocations in the Wimmera River (Chee et al. 2005; VEWH 2015). The allocations of water in the MacKenzie River system, (one of the main tributaries of the Wimmera River), fall within the Wimmera-Glenelg Bulk and Environmental Entitlements for which Grampians Wimmera Mallee Water (GWMWater) is the storage manager. Whilst coordinated use of entitlements is implied within their administrative arrangements, cooperation still proves difficult, particularly during times of water shortage when entitlement holders become focused on their individual requirements. GWMWater storage managers have, however, a duty of care to the environment in the way they operate reservoir systems and manage water delivery to both consumptive and environmental entitlement holders. Biological indices can be useful tools for water resource managers in the assessment of river health and decision making with regards to water sharing amongst the consumptive users, in order to improve environment benefits and river health, while considering potential impacts on consumptive users.

The water supply system in the Grampians was developed to deliver consumptive water for industry, agriculture and for domestic and stock consumption. Due to the recent drought-dominated regime in this area (south-east Australia), and the construction of the Wimmera-Mallee Pipeline, the share of water to users has changed significantly (Barton et al. 2011) and that available to the environment is limited. Therefore, in order to gain best value from the volume available, the water supply system in the MacKenzie River needs to be optimised towards maximising environment benefits 
from a diminished volume of water.

In the entitlement framework a storage manager is appointed to operate the supply system. Areas shaded blue are recognised as environmental water and are managed to obtain environmental objectives. This represents a situation in which environmental flow science is mostly developed and directed. Those parts in red can significantly affect the environment, but they are not managed to maximise ecosystem response.

This gap has been recognised by Department of Environment, Land, Water and Planning (formerly known as Department of Sustainability and Environment) (DELWP 2015), but it has not yet been completely addressed. Contemporary water supply system operations are guided by policy objectives and, for the Wimmera-Glenelg system, where the current project has been tested on the basis of the following policies:

duty of care to the environment (Statement of Obligations) (DELWP 2007); to facilitate environmental outcomes (listed within the Storage Manager Instrument of Appointment) (DELWP 2015); to manage consumptive flows for environmental outcomes as well (listed as a policy within the recent Western Region Sustainable Water Strategy) (DELWP 2015).

The management of water supply systems can often be constrained by a range of competing objectives. Transfers between storages are constrained by management objectives of maintaining efficiency, for transfers to be delivered in a timely manner, within operational constraints (for example, at flow rates that do not exceed valve or weir capacities). These management objectives may not be always compatible with facilitating environmental outcomes.

Annually, a total of 10,000 dam $^{3}$ of water is released from Wartook Reservoir into the MacKenzie River. Of this volume, only about 4,000 dam $^{3}$ (about one third) was released explicitly for environmental purposes. The remaining 6,000 $\mathrm{dam}^{3}$ (about two thirds) was released to meet consumptive demands and to transfer water to downstream reservoirs (GWMWater Storage Manager, pers. comm., July 17, 2015). Routine water releases from Wartook Reservoir are up to 50 dam $^{3}$ daily in summer, and 15 dam $^{3}$ daily in the winter. There can be occasional releases of up to 200 dam $^{3}$ per day, or more, if the Reservoir is full and operators need to discharge excess water. Downstream, the Mt Zero Channel has a capacity of about 30 dam $^{3}$ per day. These are significant water volumes and they pose the question "could this water be optimised to achieve positive environmental outcomes"? This comparison of volumes certainly demonstrates the potential for the MacKenzie River to be developed as a case study for a "healthy working river". The timing and route of the transfer of the consumptive water could be explored to provide environmental benefit without impacting multiple water users (Earth Tech 2004). This represents an opportunity to optimise these consumptive releases to achieve greater environmental benefits rather than relying on the smaller environmental releases alone. The use of consumptive water reduces the amount of extra environmental water needed to meet specific objectives. It seems that the $4,000 \mathrm{dam}^{3}$ (as environmental flow) may not be adequate to support all ecological requirements (Tables $\mid 1$ and $\mid 2$ ). Therefore, the ecological requirements could be better served if the consumptive allocation was configured to also aid the environmental cause. In this project, the ecological requirements have been investigated to optimise flows, with the aim of addressing major environmental requirements.

\section{Conclusions}

Rivers bring many socio-economic, geopolitical and cultural values for society world-wide, such as political power, social services, cultural initiatives, health care, sanitation, power generation, irrigation, fisheries, industries, transportations, urban and domestic water, scenic and recreational values. Indeed, rivers make a significant contribution in providing goods and services for human wellbeing. Meanwhile, rivers play a pivotal role in the maintenance of aquatic wildlife biodiversity, habitat diversity and ecosystem function. Unfortunately, most of the rivers globally are modified and regulated. In concert, rivers are both incredibly valuable and highly threatened. Therefore, the conservation of rivers is absolutely imperative, and given the incremental increase in river knowledge, this is best achieved through adaptive management because waterway managers need to update the water allocation and abstraction under adaptive management 
Table 1. Environmental flow components for the MacKenzie River at Reach 1 and 2

\begin{tabular}{|c|c|c|c|c|c|}
\hline Flow component & Timing & Magnitude & Climatic scenario & Frequency & Duration \\
\hline \multirow{3}{*}{ Cease to flow } & \multirow{3}{*}{ DEC-MAY } & \multirow{3}{*}{0 dam $^{3}$ day $^{-1}$} & Drought & \multirow{3}{*}{$\begin{array}{c}\text { As infrequently as } \\
\text { possible }\end{array}$} & $\begin{array}{l}\text { Less than } 80 \text { day } \\
\text { in total }\end{array}$ \\
\hline & & & Dry & & Jess than 30 davs \\
\hline & & & Average & & in total \\
\hline \multirow[t]{2}{*}{ Base flow } & DEC-MAY & $\begin{array}{l}2 \text { dam }^{3} \text { day }^{-1} \\
\text { or natural }\end{array}$ & All & Continuous & Continuous \\
\hline & JUN-NOV & 7 dam $^{3}$ day $^{-1}$ & All & Continuous & Continuous \\
\hline \multirow{4}{*}{ Freshes } & \multirow{2}{*}{ DEC-MAY } & \multirow{2}{*}{5 dam $^{3}$ day $^{-1}$} & Drought & 3 per period & 4-7 days \\
\hline & & & Dry & 4 per period & 4-7 days \\
\hline & \multirow{2}{*}{ DEC-MAY } & \multirow{2}{*}{50 dam $^{3}$ day $^{-1}$} & Average & 2 per period & 2-7 days \\
\hline & & & Wet & 3 per period & 2-7 days \\
\hline \multirow{8}{*}{ High flow } & \multirow{4}{*}{ JUN-NOV } & \multirow{4}{*}{55 dam $^{3}$ day $^{-1}$} & Drought & 5 per period & 2 days \\
\hline & & & Dry & 5 per period & 4 days \\
\hline & & & Wet & 5 per period & 5 days \\
\hline & & & Average & 5 per period & 7 days \\
\hline & \multirow{4}{*}{ JUN-NOV } & \multirow{4}{*}{130 dam $^{3}$ day $^{-1}$} & Drought & 1 per period & 1day \\
\hline & & & Dry & 3 per period & 2days \\
\hline & & & Wet & 5 per period & 3 days \\
\hline & & & Average & 5 per period & 4 days \\
\hline \multirow{2}{*}{ Bankfull } & \multirow{2}{*}{ Any } & \multirow{2}{*}{500 dam $^{3}$ day $^{-1}$} & Average & 1 per period & 2 days \\
\hline & & & Wet & 1 per period & 2 days \\
\hline Overbank & AUG-NOV & 900 dam $^{3}$ day $^{-1}$ & Wet & 1 per period & 1day \\
\hline
\end{tabular}

Table 2. Environmental flow components for the MacKenzie River at Reach 3

\begin{tabular}{|c|c|c|c|c|c|}
\hline Flow component & Timing & Magnitude & Climatic scenario & Frequency & Duration \\
\hline Cease to flow & DEC-MAY & 0 dam $^{3}$ day $^{-1}$ & $\begin{array}{l}\text { Drought } \\
\text { Dry } \\
\text { Average }\end{array}$ & $\begin{array}{l}\text { As infrequently } \\
\text { as possible }\end{array}$ & $\begin{array}{l}\text { Less than } 80 \text { day } \\
\text { in total } \\
\text { Less than } 30 \text { days } \\
\text { in total }\end{array}$ \\
\hline Base flow & Any & $\begin{array}{l}10 \text { dam }^{3} \text { day }^{-1} \\
\text { or natural }\end{array}$ & All & Continuous & Continuous \\
\hline \multirow{5}{*}{ Freshes } & \multirow{3}{*}{ DEC-MAY } & \multirow{3}{*}{35 dam $^{3}$ day $^{-1}$} & Drought & 3 per period & 2-7 days \\
\hline & & & Dry & 3 per period & 3-7 days \\
\hline & & & Average & 4 per period & 3-7 days \\
\hline & \multirow[b]{2}{*}{ JUN-NOV } & \multirow[b]{2}{*}{35 dam $^{3}$ day $^{-1}$} & $\begin{array}{c}\text { Wet } \\
\text { Drought }\end{array}$ & \multirow[b]{2}{*}{5 per period } & $\begin{array}{l}\text { 3-7 days } \\
2 \text { days }\end{array}$ \\
\hline & & & $\begin{array}{c}\text { Dry } \\
\text { Average } \\
\text { Wet }\end{array}$ & & $\begin{array}{l}4 \text { days } \\
5 \text { days } \\
7 \text { days }\end{array}$ \\
\hline High flow & JUN-NOV & 190 dam $^{3}$ day $^{-1}$ & $\begin{array}{c}\text { Average } \\
\text { Wet }\end{array}$ & 1 per period & $\begin{array}{l}1 \text { day } \\
2 \text { days }\end{array}$ \\
\hline Bankfull & Any & 500 dam $^{3}$ day $^{-1}$ & Wet & 1 per period & 1 day \\
\hline Overbank & AUG-NOV & 1000 dam $^{3}$ day $^{-1}$ & Wet & 1 per period & 1day \\
\hline
\end{tabular}


processes including monitoring, operational rules, implementation, assessment and planning.

While management usually focuses on environmental flow allocation as the means of improving stream condition, this study highlights the benefits that can arise from flows tied to consumptive water transfers and opens the way to address the ongoing challenge for river scientists and water engineers in providing ecological benefits from scarce water. This study shows that benefits can accrue when management moves from a contest between volumes to allocations and abstraction. Considerable environmental benefits can be gained from the configuration of consumptive flows by rigorous adaptive management in engineered and modified rivers. Evaluation of river health, stream condition and water quality identify the causes and threats of the ecological disturbances and flows alteration in riverine ecosystems, which is very important for river management and water sharing. Suggested operational protocols, strategic rules and recommendations are provided in chapter 6 and are based on the water-release events to improve ecological condition in three different reaches of the MacKenzie River. These operational rules are derived by the amalgamation of environmental flows and consumptive flows from the main attributes of the flow regimes, including magnitude, duration, variation, timing and frequency.

At present only 4000 dam $^{3}$ is allocated for environmental flows for the MacKenzie River. This volume would only allow for approximately 10 dam $^{3}$ per day in each year. This study showed that the volume of allocated water for the MacKenzie River as environmental flows did not meet the ecological requirements, particularly in the lower reaches. However, good ecological condition can be achieved if consumptive flows are also released in a manner that benefits the ecology of the River. There are certain constraints on the release of this water, but where consumptive flow release operations are developed with environmental flow operations (10 dam $^{3}$ daily for 12 months) a flow of 35 dam $^{3}$ daily for three days every two weeks as a top-up from consumptive flows can be achieved. Indeed, there are clear benefits that would accrue from integrating environmental flows and consumptive flow operations. This would be achieved by respective operators exchanging flow release plans and for this to be coordinated between water agencies (GWMwater,
WCMA and DELWP). The agencies have this as a planning goal and so the way is paved for more effective use of all water releases.

Overall, evidence-based decisions and strategies in water resources management are imperative today due to scarce water availability. Therefore, the development of hydroecological models (e.g. statistical models) has been accelerated to provide accurate evidence for water managers in terms of an understanding of antecedent condition, hydrologic alterations, ecological responses and ecological limits for those alterations in riverine ecosystems.

\section{Acknowledgments}

The authors would like to thank Grampians Wimmera Mallee Water (GWMWater, Australia), Federation University (Australia) and University of Tabriz (Iran) for their supports. The authors would also like to thank the anonymous reviewers for their valuable comments and corrections that much improved the final version of the manuscript.

\section{References}

Alluvium, 2013, Wimmera River environmental flows study. Report by Alluvium Consulting Australia for Wimmera Catchment Management Authority, Horsham, 132 pp.

Anderson J.R., Morison A.K., 1989a, Environmental flow studies for the Wimmera River, Victoria - Part A: Introduction, catchment features, hydrology, fundamental concepts and practical considerations. Technical Report Series No.73, Arthur Rylah Institute for Environmental Research, Shepparton.

Anderson J.R., Morison A.K., 1989b, Environmental flow studies for the Wimmera River, Victoria - Part B: Fish habitat assessment. Technical Report Series No. 74, Arthur Rylah Institute for Environmental Research, Shepparton.

Anderson J.R., Morison A.K., 1989c, Environmental flow studies for the Wimmera River, Victoria - Part C: Water quality and the effects of an experimental release of water. Technical Report Series No. 75, Arthur Rylah Institute for Environmental Research, Shepparton.

Atazadeh E., 2017, Algae-based models to configure consumptive flows for ecological benefit in the highly regulated MacKenzie River, south-east Australia [PhD Thesis], Federation University Australia, Victoria, 346 pp.

Atazadeh E., Barton A., Shirinpour M., Zarghami M., Rajabifard A., 2020, River management and environmental water allocation in regulated ecosystems of 
arid and semiarid regions - A review, Fundam. Appl. Limnol. 193(4): 327-345.

[BoM] Bureau of Meteorology, 2014, Climate Glossary [electronic resource], Bureau of Meteorology, Melbourne (Accessed 3 Jun 2015). Retrieved from http:// www.bom.gov.au/climate/glossary/

[BoM], 2016, Murray-Darling Basin: Geographic information [electronic source] Bureau of Meteorology, Melbourne (Accessed 3 Jun 2015). Retrieved from http://www.bom.gov.au/water/nwa/2016/mdb/regiondescription/geographicinformation.shtml

Barr C.S, 2010, Droughts and flooding rains: a fine-resolution reconstruction of climatic variability in Western Victoria, Australia, over the last 1500 years [Ph.D. Thesis], University of Adelaide, Adelaide, $324 \mathrm{pp}$.

Barton A., Briggs S., Williams A.G., Prior D., 2011, Coping with severe drought: Stories from the front line, Austr. J. Water Res. (AJWR) 15(1): 21-32.

Birch W.D., 2003, Geology of Victoria, Geological Society of Australia (Victoria Division), Melbourne, $842 \mathrm{pp}$.

Bond N., Lake P.S., Arthington A., 2008, The impacts of drought on freshwater ecosystems: an Australian perspective, Hydrobiologia 600(1): 3-16.

Boulton A.J., Brock M.A., 1999, Australian Freshwater Ecology. Processes and Management, Gleneagles Publishing, Canberra, 300 pp.

Boulton A.J, Brock M.A, Robson B.J., Ryder D.S., Chambers J.M., Davis J.A., 2014, Australian freshwater ecology. Processes and management, Wiley-Blackwell, Chichester, 386 pp.

Brandis K., Nairn L., Porter J., Kingsford R., 2009, Preliminary assessment for the environmental water requirements of waterbird species in the Murray Darling Basin, University of New South Wales, Sydney, 86 pp.

Bunn S.E., Arthington A.H., 2002, Basic principles and ecological consequences of altered flow regimes for aquatic biodiversity, Environ. Manage. 30(4): 492 507.

Cai W., Cowan T., Sullivan A., 2009, Recent unprecedented skewness towards positive Indian Ocean Dipole occurrences and its impact on Australian rainfall, Geophys. Res. Lett. 36(11): \#L11705.

Cayley R., Taylor D., 1997, Grampians special map area geological report, Department of Natural Resources and Environment, Melbourne, $150 \mathrm{pp}$.

Chee Y., Burgman M., Carey J., 2005, Use of a Bayesian Network decision tool to manage environmental flows in the Wimmera River, Victoria. Report No. 4, LWA/MDBC Project UMO43: Delivering sustainability through risk management, University of Melbourne, Melbourne, 76 pp.

Clark I.D., 2010, Colonial tourism in Victoria, Australia, in the 1840s: George Augustus Robinson as a nascent tourist, Int. J. Tour. Res. 12(5): 561-573.

Clarke F.G., 2002, The history of Australia, Greenwood Press, Westport, $256 \mathrm{pp}$.

Cowell A.L., Matthews T.G., Lind P.R., 2006, Effect of fire on benthic algal assemblage structure and recolonization in intermittent streams, Austral Ecol. 31(6): 696-707.

Craigie N.M., Brizga S.O., Condina P., 1999, Waterway management strategy [Investigation report draft], Wimmera Catchment Authority, Horsham.

[DELWP] Department of Environment, Land, Water and Planning, 2007, Statement of obligations, Grampians Wimmera Mallee Water Authority, 16 pp.

[DELWP] Department of Environment, Land, Water and Planning, 2015, Water allocation framework [electronic resource], DELWP, Melbourne (Accessed $10 \mathrm{Sep}$ 2015). Retrieved from http://www.depi.vic.gov.au/ water/rivers-estuaries-and-wetlands/strategy-and-planning.

[DNRE] Department of Natural Resources and Environmental, 2000a, Threatened vertebrate fauna in Victoria - 2000. A systematic list of vertebrate fauna considered extinct, at risk of extinction or in major decline in Victoria, DNRE, Melbourne.

[DNRE] Department of Natural Resources and Environmental, 2000b, Atlas of Victorian wildlife (electronic fauna database). Flora and Fauna Program, DNRE, Heidelberg.

[DNRE] Department of Natural Resources and Environmental, 2000c, Wetlands Database (electronic waterbird and wetland database). Flora and Fauna Program, DNRE, Heidelberg.

[DWR] Department of Water Resources, 1989, Water Victoria: A resource handbook, Department of Water Resources of Victoria, Melbourne, $311 \mathrm{pp}$.

Earth Tech, 2004, MacKenzie River waterway action plan [Report], Earth Tech Engineering Pty Ltd, Melbourne, $68 \mathrm{pp}$.

Ecological Associates, 2004, The environmental water needs of the Wimmera terminal lakes - Final report, Ecological Associates, Adelaide.

Enright N., Goldblum D., Ata P., Ashton D., 1997, The independent effects of heat, smoke and ash on emergence of seedlings from the soil seed bank of a heathy Eucalyptus woodland in Grampians (Gariwerd) National Park, western Victoria, Austr. J. Ecol. 22(1): 81-88.

Feng M., Meyers G., 2003, Interannual variability in the tropical Indian Ocean: a two-year time-scale of Indian Ocean Dipole, Deep Sea Res. II 50(12-13): 22632284.

Fischer R.A., 1999, Wheat cropping in Australia, [in:] Satorre E.H., Slafer G.A. (eds), Wheat: ecology and physiology of yield determination, Food Products Press, New York: 277-294.

Fogt R.L., Bromwich D.H., 2006, Decadal variability of the ENSO teleconnection to the high-latitude South Pacific governed by coupling with the Southern Annular Mode, J. Climate 19(6): 979-997.

Gehrke P., Brown P., Schiller C., Moffatt D., Bruce A., 1995, River regulation and fish communities in the 
Murray-Darling river system, Australia, Regul. Rivers: Res. Manage. 11(3-4): 363-375.

Gell P.A., 1997, The development of a diatom database for inferring lake salinity, western Victoria, Australia: towards a quantitative approach for reconstructing past climates, Austr. J. Bot. 45: 389-423.

Gill A.M., Moore P.H., 1996, Ignitibility of leaves of Australian plants. A contract report to the Australian Flora Foundation, CSIRO Plant Industry, Canberra, 34 pp.

Gillett N., Kell T., Jones P., 2006, Regional climate impacts of the Southern Annular Mode, Geophys. Res. Lett. 33(23): \#L23704.

Goodwin I., Van Ommen T., Curran M., Mayewski P., 2004, Mid latitude winter climate variability in the South Indian and southwest Pacific regions since 1300 AD, Clim. Dyn. 22(8): 783-794.

[GWMWater] Grampians Wimmera Mallee Water Corporation, 2012, Water quality data. Major storages: October 2011-November 2012, GWMWater, Horsham.

Hendon H.H., Thompson D.W., Wheeler M.C., 2007, Australian rainfall and surface temperature variations associated with the Southern Hemisphere Annular Mode, J. Clim. 20(11): 2452-2467.

House M., Kohn B., Farley K., Raza A., 2002, Evaluating thermal history models for the Otway Basin, southeastern Australia, using (U-Th)/He and fission-track data from borehole apatites, Tectonophysics 349(1): 277-295.

Joyce E.B, 1988, Cainozoic volcanism in Victoria, [in:] Clark I.F., Cook B.J. (eds), Victorian geology excursion guide, Austr. Acad. Sci., Canberra: 71-80.

Karpechko A.Y., Gillett N.P., Marshall G.J., Screen J.A., 2009, Climate impacts of the southern annular mode simulated by the CMIP3 models, J. Clim. 22(13): 3751-3768.

Kiem A.S., Franks S.W., 2004, Multi-decadal variability of drought risk - Eastern Australia, Hydrol. Process. 18(11): 2039-2050.

Kiem A.S., Franks S.W, Kuczera G., 2003, Multi-decadal variability of flood risk, Geophys. Res. Lett. 30(2): \#1035.

Kingsford R.T., 2011, Conservation management of rivers and wetlands under climate change - a synthesis, Mar. Freshw. Res. 62(3): 217-222.

Lake P.S, Barmuta L., Boulton A., Campbell I., St Clair R., 1985, Australian streams and Northern Hemisphere stream ecology: comparisons and problems, Proc. Ecol. Soc. Aust. 14: 61-82.

Lake P.S, Palmer M.A., Biro P., Cole J., Covich A.P., Dahm C., Gibert J., Goedkoop W., Martens K., Verhoeven J., 2000, Global change and the biodiversity of freshwater ecosystems: Impacts on linkages between above-sediment and sediment biota, BioScience 50(12): 1099-1107.

Lake P.S., 2011 , Drought and aquatic ecosystems: effects and responses, Wiley-Blackwell, Chichester, 381 pp.
Lawrence C.R., 1975, Geology, hydrodynamics and hydrochemistry of the southern Murray basin. Geological Survey of Vic. Memoir 30. Vol. 1, Mines Dept. Vic., Melbourne, 169 pp.

Lisitsin V., González-Álvarez I., Porwal A., 2013, Regional prospectivity analysis for hydrothermal-remobilised nickel mineral systems in western Victoria, Australia, Ore Geol. Rev. 52: 100-112.

Maheshwari B., Walker K., McMahon T., 1995, Effects of regulation on the flow regime of the River Murray, Australia, Regul. Rivers: Res. Manage. 10(1): 15-38.

Maier, H. R., Burch M.D., Bormans M., 2001, Flow management strategies to control blooms of the cyanobacterium, Anabaena circinalis, in the River Murray at Morgan, South Australia, Regul. Rivers: Res. Manage. 17(6): 637-650.

Marshall G.J., 2003, Trends in the Southern Annular Mode from observations and reanalyses, J. Climate 16(24): 4134-4143.

Meyers G., McIntosh P., Pigot L., Pook M., 2007, The years of El Nińo, La Nińa, and interactions with the tropical Indian Ocean, J. Climate 20(13): 2872-2880.

Mosley L.M., Zammit B., Leyden E., Heneker T.M., Hipsey M.R., Skinner D., Aldridge K.T., 2012, The impact of extreme low flows on the water quality of the Lower Murray River and lakes (South Australia), Water Resour. Manag. 26(13): 3923-3946.

Murphy B.F., Timbal B., 2008, A review of recent climate variability and climate change in southeastern Australia, Int. J. Climatol. 28(7): 859-879.

Nathan R., Lowe L., 2012, The hydrologic impacts of farm dams, Austr. J. Water Res. (AJWR) 16(1): 75-83.

Nicholls N., 1988, El Nino-Southern oscillation and rainfall variability, J. Climate 1(4): 418-421.

Nielsen D., Brock M., Rees G., Baldwin D.S., 2003, Effects of increasing salinity on freshwater ecosystems in Australia, Austr. J. Bot. 51(6): 655-665.

Overman T., 1996, Draft Wimmera River environmental flows [Technical report], Department of Natural Resources and Environment, Horsham.

Power S., Casey T., Folland C., Colman A., Mehta V., 1999, Inter-decadal modulation of the impact of ENSO on Australia, Clim. Dyn. 15(5): 319-324.

Rosengren N., 1999, Geology and geomorphology of Victoria's grassland regions, [in:] Jones R. (ed.), The Great Plains Crash. Proc. of Conference on the Grasslands and Grassy Woodlands of Victoria, Victorian Institute of Technology, Melbourne: 7-10.

[RWC] Rural Water Commission, 1991, Wimmera-Mallee system study. Draft Main Report, Rural Water Commission of Victoria, Melbourne.

Saji N., Yamagata T., 2003, Possible impacts of Indian Ocean dipole mode events on global climate, Clim. Res. 25(2): 151-169.

[SKM] Sinclair Knight Merz, 2002, Stressed rivers project - Environmental flows study. Wimmera River, Sinclair Knight Merz, Melbourne. 
[SKM] Sinclair Knight Merz, 2003, Monitoring environmental flows in the Wimmera and Glenelg Rivers, Sinclair Knight Merz, Melbourne.

[VEWH] Victorian Environmental Water Holder, 2015, Seasonal watering proposal for the Wimmera system 2015-16, Wimmera CMA, Horsham.

Wang G., Hendon H.H., 2007, Sensitivity of Australian rainfall to inter-El Nino variations, J. Climate 20(16): 4211-4226.

Westbury A.-M., Tiller D., Metzeling L., 2007, Environmental flows and ecological health of the lower Wimmera River, [in:] Wilson A.L., Dehaan R.L., Watts R.J., Page K.J., Bowmer K.H., Curtis A. (eds), Proc. of the 5th Australian Stream Management Conference "Austarlian rivers: makimng a difference", Charles Sturt University, Thurgoona, 449-454.
Western A.W., 1994, The behaviour of salinity and density stratified flows in the Wimmera River, Australia [Ph.D. Thesis], University of Melbourne, Melbourne, 404 pp.

Western A.W., Finlayson B.L., McMahon T.A, O'Neill I.C., 1997, A method for characterising longitudinal irregularity in river channels, Geomorphology 21(1): 39-51.

Whelan R., 1995, The Ecology of fire, Cambridge University Press, Cambridge, 346 pp.

Willatt S.T., Pullar D.M., 1984, Changes in soil physical properties under grazed pastures, Austr. J. Soil Res. 22(3): 343-348.

[WRCLPB] Wimmera Regional Catchment and Land Protection Board, 1997, Wimmera regional catchment strategy, WRCLPB, Horsham, 39 pp. 